\title{
湿式材料プロセスにおける機能性微粒子の表面設計と集合構造制御

\author{
Surface Modification and Alignment Structure Control of \\ Functional Particles for Wet Material Processing
}

\author{
飯島志行*・多々見 純一* \\ Motoyuki IIJIMA and Junichi TATAMI
}

Key Words: Functional Particle, Surface Modification, Dispersion, Alignment, Wet Processing

\section{1. 緒言}

二次電池や蓄電デバイス、環境浄化触媒やその担体、高 効率・省エネルギー型の小型電子部材などを例とした各種 のエネルギー・環境関連材料は、電気的特性、触媒活性、 熱的特性、力学的特性などの役割を担う機能性微粒子・ナ ノ粒子を原料として組み合わせ、混合、成形、熱処理等の プロセスを経て複合材料として部材化されている。これら 複合材料の機能性は、複合材料中における微粒子・ナノ粒 子の分散状態および集合構造に依存していることも多く、 材料の製造過程でその積極的かつ自在な制御の実現が求め られる。複数の微粒子.ナノ粒子を原料素材として最終製 品にプロセッシングする手法は、乾式プロセスや湿式プロ セスを含め、各々の特徵と利点を生かした手法が検討され ている。本稿では、複雑形状の成形や連続生産への期待も 大きい湿式法における機能性微粒子・ナノ粒子のプロセッ シングを対象とし、特に非水系溶媒中における微粒子・ナ ノ粒子の分散安定化に向けた表面設計技術について概説し た後に、微粒子集合構造制御技術への展開事例を、筆者ら が取り組んできた内容を中心に紹介する。

\section{2. 機能性微粒子・ナノ粒子の均一分散のための表面設計}

湿式材料プロセスにおける機能性微粒子.ナノ粒子の集 合構造制御にむけては、まず各種溶媒中での機能性微粒子. ナノ粒子の均一分散法を構築する必要がある。非水系溶媒 中における機能性微粒子.ナノ粒子の分散化に向けた表面 設計指針については既報でまとめた ${ }^{1)}$ が、概要を述べると、 微粒子・ナノ粒子の粗大凝集体を生成しないような手法を 用いて、機能性微粒子上に溶媒との化学的親和性の高い有 機官能基を、十分な修飾剤密度となるように、粒子表面上 に固定化する必要がある。
具体的な事例については、これまでの既報の総説等 2)-4) で概説してきたが、機能性微粒子・ナノ粒子の粗大凝集体 の生成を抑制した表面処理プロセスとしては、静電相互 作用により親水性溶媒中で分散安定化された微粒子・ナノ 粒子に対して直接表面修飾剂を吸着させる手法 ${ }^{5)-8)}$ 、微粒 子の合成と同時に表面修飾剂を固定化させる手法 ${ }^{9)}$ 、表面 修飾剂で保護された微粒子の分散体に対して別の表面修飾 剂を過剩に作用させて表面修飾剤を置き換える配位子交換

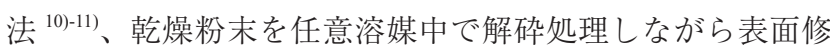

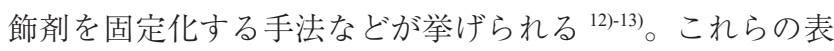
面処理プロセス時に、分散対象としている微粒子に効果的 に吸着する官能基と、分散媒との親和性が高い有機鎖をあ わせ持つ表面修飾剂を設計・選定し、飽和吸着条件となる ような添加量を加えることで、機能性微粒子の非水系溶媒 中での分散安定化が実現する事例が多い。

一例として、静電反発力により安定化された $\mathrm{TiO}_{2}$ ナノ 粒子の水/アルコール系分散体に、 $\mathrm{TiO}_{2}$ ナノ粒子に対して 高い吸着性をもつリン酸基とトルエンなどの低極性溶媒と 高い親和性をもつオレイル基で構成されるリン酸オレイル を、 $\mathrm{TiO}_{2}$ ナノ粒子上に飽和吸着する量だけ添加する手法が 挙げられる ${ }^{5}$ 。水系分散体として安定に分散していた親水 性 $\mathrm{TiO}_{2}$ ナノ粒子は、リン酸オレイルの吸着に伴ってその表 面は疎水化され、水系溶媒中で一端ゆるい凝集体を生成す る。 $\mathrm{TiO}_{2}$ ナノ粒子が十分にリン酸オレイルで被覆されてい れば、得られた凝集体を回収、洗浄後、トルエンなどの低 極性溶媒中に加えて超音波処理を施すことで均一分散化が 可能である。表面修飾剤として、アルコキシド基の加水分 解と金属酸化物粒子表面の水酸基に対する縮合反応を経て 粒子上に化学的に固定化されるシランカップリング剂のう ち、有機官能基として疎水鎖をもつデシルトリメトキシシ ランを用いても同様の操作で $\mathrm{TiO}_{2}$ ナノ粒子を低極性溶媒に

* 横浜国立大学大学院 環境情報研究院（＝240-8501 神奈川県横浜市保土ヶ谷区常盤台 79-7）

Yokohama National University, Graduate School of Environment and Information Sciences

(79-7 Tokiwadai, Hodogaya-ku, Yokohama, Kanagawa, 240-8501 Japan) 
分散安定化できる ${ }^{7)}$ 。

微粒子表面の溶媒に対する親和性を適合させる手法とし ては、異なる有機鎖を持つ表面修飾剤を複数組み合わせる 手法や ${ }^{8)}$ 、様々な有機溶媒に高い親和性を示すような有機 鎖構造をもつ表面修飾剤を設計する手法 ${ }^{6}$ が有用である。 例えば前者では、上述した $\mathrm{TiO}_{2}$ ナノ粒子に対するシラン カップリング処理時に、有機鎖として疎水鎖をもつデシル トリメトキシシランと、親水基を持つアミノプロピルシラ ンを溶媒に応じた比率で適宜組み合わせることで、へキサ ン、メチルエチルケトン、ジメチルスルホキシドなど各種 の溶媒に $\mathrm{TiO}_{2}$ ナノ粒子を均一分散化できる ${ }^{8)}$ 。また、溶媒 に適合する適切な有機鎖構造が選定できれば、ビーズミル をはじめとした物理的解砕処理と合わせた処理によって気 相法等により製造されたナノ粒子乾燥粉末の液中分散化も 可能である ${ }^{12)}$ 。後者では、Fig.1に示すような吸着基付近 で親水鎖と疎水鎖に分岐する特異な構造を持つ機能性界面 活性剤を飽和吸着させるだけで、 $\mathrm{TiO}_{2}$ ナノ粒子を各種の溶 媒や樹脂材料に均一分散できることを報告している6)。

ところで、Fig.1に示したような分散に優位な有機鎖をも つ表面修飾剤が、必ずしも材料プロセッシングで利用した い粒子材質の表面に効果的に固定できるとは限らない。例 えばFig.1 に示した表面修飾剤は $\mathrm{TiO}_{2}$ ナノ粒子には効果的 に吸着するが、 $\mathrm{SiO}_{2}$ ナノ粒子等には吸着しにくい。そのよ うな場合は、Fig.1に示したような、ポリエチレンイミン (PEI) などのカチオン性高分子を介して表面修飾剤を固定化 する交互吸着法の利用が解決策の一つである ${ }^{10)}$ 。Fig.1には、 ゾルゲル法により調製した $\mathrm{SiO}_{2}$ ナノ粒子に対して直接 PEI を飽和吸着させた後に同図中の機能性界面活性剤を吸着さ せたナノ粒子と、合成と修飾の同時操作によりオレイルア ミンで保護した $\mathrm{Ag}$ ナノ粒子に対して配位子交換法により PEI を固定化した後に同図中の機能性界面活性剂を吸着さ せたナノ粒子を、各種の有機溶媒に超音波分散させた様子 である。 $\mathrm{SiO}_{2}$ ナノ粒子、 $\mathrm{Ag}$ ナノ粒子いずれの場合も交互 吸着操作を経た機能性有機鎖の固定化に伴って、各種の溶

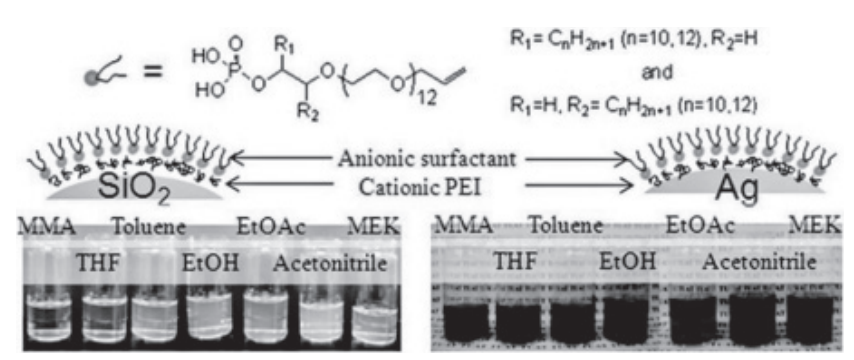

Fig.1 Chemical structure of functional anionic surfactant with branched structure and various suspensions of $\mathrm{SiO}_{2}$ and $\mathrm{Ag}$ nanoparticles surface modified with functional surfactant through layer by layer process using poyethyleneimine (PEI). (Reprinted with permission from Ref. 10. Copyright 2010 American Chemical Society.)
媒に均一分散が可能であった。

\section{3. 機能性微粒子の集合構造制御への展開}

前項で述べた手法に基づき、様々な材質の機能性微粒子. ナノ粒子を所望の溶媒中に分散安定化できる事例が着実に 増えている現在、これらの分散性微粒子・ナノ粒子の集合 配列状態を、湿式プロセッシングの過程でいかに制御する かが次の課題となる。

Fig.2には、PEI を介してアニオン性界面活性剤を修飾し た Fig.1 で示した $\mathrm{SiO}_{2}$ ナノ粒子を、表面未修飾の各種微粒 子 $\left(\mathrm{SiO}_{2}\right.$ 、グラシーカーボン、架橋型ポリスチレン $)$ とト ルエン中で混合した様子を示す ${ }^{14)}$ 。表面修飾した $\mathrm{SiO}_{2}$ ナノ 粒子が効率的に $\mathrm{SiO}_{2}$ 、グラシーカーボン、架橋型ポリスチ レン微粒子上に固定化されているうえ、複合粒子の最表面 には各種溶媒へ高い親和性を呈する機能性有機鎖で修飾さ れたナノ粒子で被覆されているため、複合粒子として各種 溶媒中に分散安定化が可能であった。 $\mathrm{SiO}_{2}$ ナノ粒子の吸着 メカニズムは現在検討中であるが、 $\mathrm{SiO}_{2}$ ナノ粒子表面上に 固定化されたPEI とアニオン性界面活性剂のうち、PEI 層 を介して微粒子上に固定化されたものと考えている。

Fig.2で示したナノ粒子の湿式複合化技術は、微粒子以 外の母材に適用可能である。例えば、Fig.3には Fig.1 で示 したPEI と機能性界面活性剂で修飾した Agナノ粒子を溶 媒中でアラミドナノファイバーと混合することで得られた

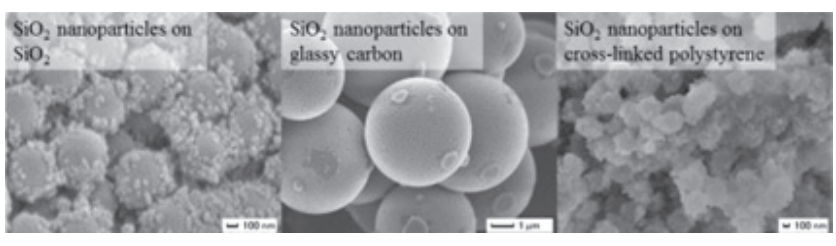

Fig.2 FE-SEM images of $\mathrm{SiO}_{2}$, glassy carbon and cross-linked polystyrene spheres mixed with $\mathrm{SiO}_{2}$ nanoparticles surface modified with PEI and anionic surfactant in toluene. (Reprinted with permission from Ref.14. Copyright 2014 Elsevier.)
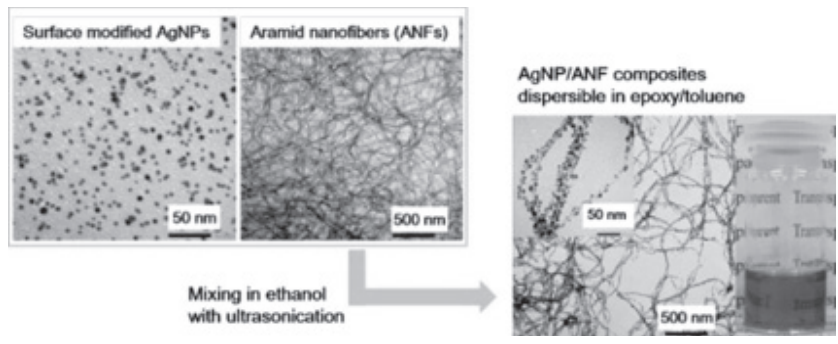

Fig.3 Ag nanoparticles (NPs) surface modified with PEI and anionic surfactant, aramid nanofiber (ANF), and Ag/ANF composites prepared by mixing Ag NPs and ANF in organic solvents. (Reprinted with permission from Ref.15, Copyright 2015 Elsevier.) 
複合体の様子である ${ }^{15)}$ 。混合前のアラミドナノファイバー は、ナノサイズの代表径を有しているものの、ファイバー 間が強く凝集していた。一方、表面修飾が施された分散性 $\mathrm{Ag}$ ナノ粒子と混合することで、Agナノ粒子がアラミドナ ノファイバー上に効果的に固定化されたうえ、アラミドナ ノファイバーの強い凝集構造が解かれている様子が確認で きる。さらに、Fig.2の場合と同様に、アラミドナノファ イバーは各種の有機溶媒に分散可能である有機鎖で修飾さ れた $\mathrm{Ag}$ ナノ粒子で被覆されているため、得られた複合体 はトルエン（エポキシ樹脂混合溶液をはじめとした溶媒に 分散が可能であった。本技術は、ナノ粒子の粗大凝集の生 成を防止しながらアラミドナノファイバーを介したナノ粒 子の配列化技術と見ることも可能であり、湿式材料プロセ ス中における微粒子の分散配列制御技術として一つの有用 なアプローチとして期待できる。

\section{4. カチオン性高分子とオレイン酸の会合体による簡便な 表面設計プロセスの構築}

上述したPEI を介してアニオン性界面活性剤を修飾した ナノ粒子は、溶媒中に扔ける微粒子・ナノ粒子の湿式複 合化や母材粒子をテンプレートとした配列化に有用である が、表面修飾操作の過程では予めナノ粒子に対する PEI の 飽和吸着条件を求めたのち、アニオン性界面活性剤の単層 被覆条件を求めておく必要があり、その操作は煩雑である。 この課題を解決するため、筆者らは予めPEIにアニオン性 界面活性剂や脂肪酸を会合させた後に、微粒子表面上に固 定化することで微粒子の分散配列制御を実現する、より簡 便な手法を提案している ${ }^{16)}$ 。

Fig.4には、非水系溶媒であるトルエン中に、各種分子量 のPEI と、PEIの単位ユニット構造であるエチレンイミン (EI) 量に対して 2 および $5 \mathrm{~mol} \%$ 相当のオレイン酸を加えて 超音波処理と擋挥を施した溶液の様子である ${ }^{16)}$ 。PEI は親 水性のカチオン性高分子であるため、トルエンなどの非水 系溶媒には不溶である。一方、オレイン酸とともにトルエ ンに懸濁させると、オレイン酸量が増加するにしたがって 次第にPEI は可溶化した。Fig.5には、トルエン、オレイン 酸、PEI、およびPEI とオレイン酸を混合した溶液の FTIRATR スペクトルを示す。オレイン酸のIRスペクトルから は-COOH 型の吸収が認められた一方で、オレイン酸を介 在させて PEI を可溶化したトルエン溶液からは、トルエン、 PEI に帰属される吸収に加えて、カルボン酸塩 $\left(\mathrm{COO}^{-}\right)$型の 対称伸縮振動と逆対称伸縮振動の吸収が確認された。また、 オレイン酸の添加量が少ない条件では- $\mathrm{COOH}$ 型のカルボ ン酸の吸収は認められず、オレイン酸の添加量が増大する と次第に-COOH 型の吸収が検出される傾向も観察された。 以上のことから、トルエン中でオレイン酸のカルボン酸が PEI のアミノ基に会合することで PEI が部分的に疎水化さ れ、PEI とオレイン酸の会合体としてトルエンに可溶化し

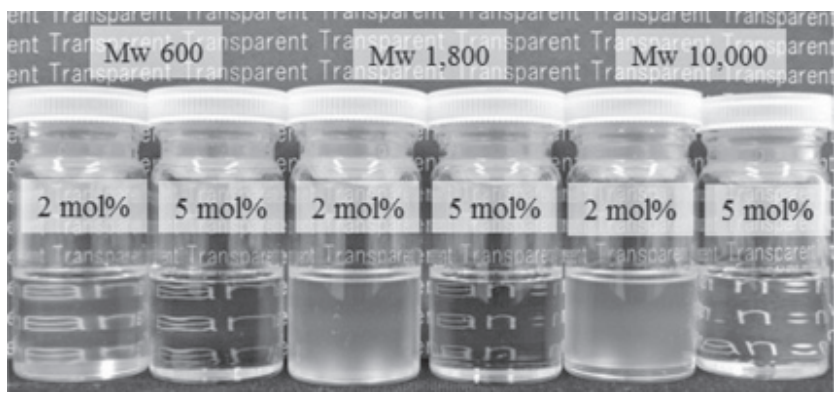

Fig.4 Photograph of PEI/toluene solution with 2 and $5 \mathrm{~mol} \%$ addition of OA. (Reprinted with permission from Ref. 16. Copyright 2015 American Chemical Society.)

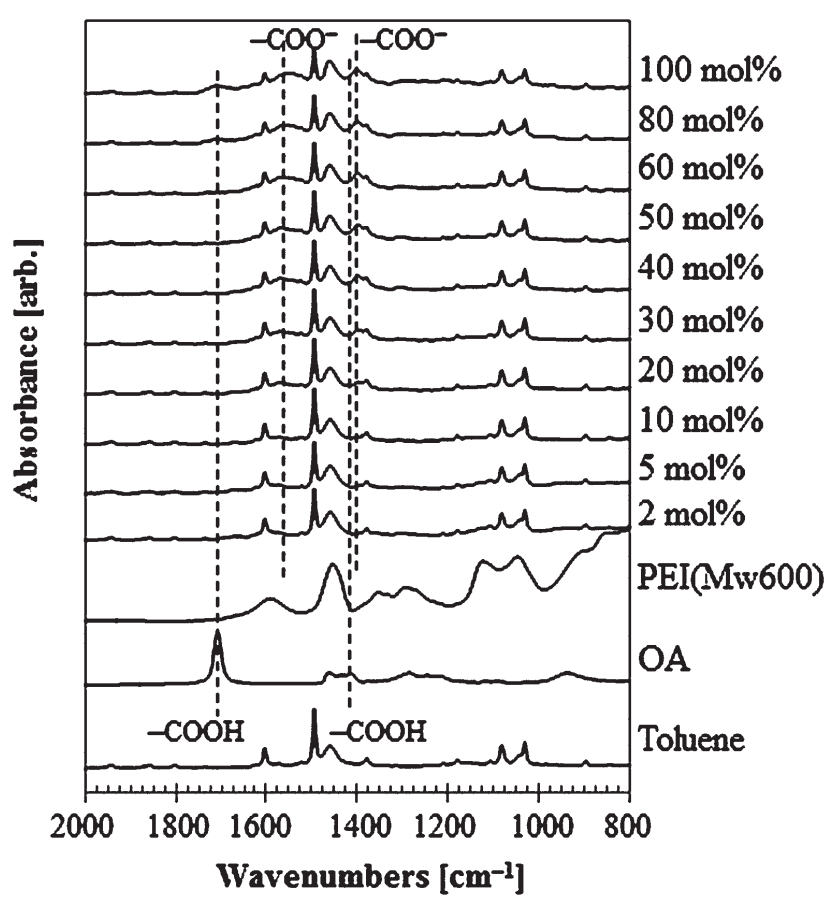

Fig.5 FT-IR spectra of toluene, OA, PEI (Mw 600) and PEI-OA with various OA additive contents. (Reprinted with permission from Ref. 16. Copyright 2015 American Chemical Society.)

たものと考えられる。また、オレイン酸の添加量が EIユニッ 卜に対しておよそ $80 \mathrm{~mol} \%$ を超えると、会合体を形成しな いフリーなオレイン酸が存在し始めることも Fig.5 から推 察できる。

Fig.6にはPEI (Mw 1800)に、EI ユニット数に対して 30 $\mathrm{mol} \%$ のオレイン酸をトルエン中で会合することで調製し たPEI とオレイン酸の会合体（PEI-OA 会合体）を、 $\mathrm{SiO}_{2}$ ナノ粒子の表面修飾剤として適用した事例を示す ${ }^{17)}$ 。粒子 径がc.a.25 nm の $\mathrm{SiO}_{2}$ ナノ粒子が高度に分散した水系分散 体を出発原料とし、2-プロパノールの添加により $\mathrm{SiO}_{2}$ ナ 

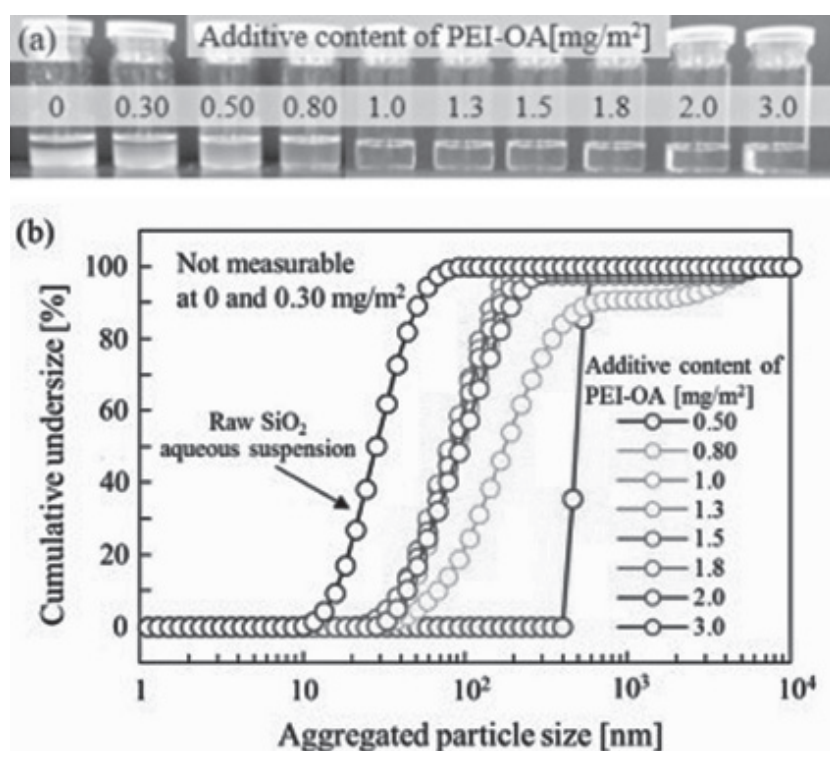

Fig.6 (a) Photograph of PEI-OA-modified $\mathrm{SiO}_{2} /$ toluene suspensions (2.8 vol\%); (b) effect of the additive content of PEI-OA on the cumulative particle size distribution of $\mathrm{SiO}_{2}$ /toluene suspensions (0.44 vol\%). (Reprinted from Ref. 17, Copyright 2016, with permission from Elsevier.)

ノ粒子を緩く凝集させた後に遠心分離することで回収した ケーキ層に、様々な添加量の PEI-OA 会合体を溶解したト ルエンを加えて超音波分散することで得た分散液の様子を Fig.6(a)に示す。また、得られた各分散体中における $\mathrm{SiO}_{2}$ ナノ粒子の粒子径分布を動的光散乱法により評価した結 果をFig.6(b) に示す。PEI-OA 会合体を添加しない系では、 $\mathrm{SiO}_{2}$ ナノ粒子がトルエン中で即座に凝集したが、PEI-OA 会合体の添加量増大に伴って $\mathrm{SiO}_{2}$ ナノ粒子は分散安定化す るようになり、およそ $1.3 \mathrm{mg} / \mathrm{m}^{2}$ 以上の添加条件では 100 $\mathrm{nm}$ 以下の凝集径で高度に分散した $\mathrm{SiO}_{2}$ ナノ粒子の分散体 を得ることに成功している。Fig.1に示すような操作手順 の多い交互吸着操作を経なくても、単純な混合操作で調製 可能な PEI と脂肪酸の会合体を添加するだけで、機能性微 粒子の溶媒中での分散安定化が実現した。

また、PEI と脂肪酸の会合体の固定化により分散安定化 したナノ粒子は、Fig.1で示したナノ粒子と同様に、表面 未修飾の母材粒子に対する湿式複合化と液中での分散安定 化を同時に達成することも可能である。例えば、Fig.7は Fig.6で調製したPEI-OA 会合体で安定化した $\mathrm{SiO}_{2}$ ナノ粒 子と $\mathrm{Ni}$ 微粒子をトルエン中で混合した後、磁気分離によ り $\mathrm{Ni}$ 微粒子および $\mathrm{Ni}$ 微粒子に吸着した $\mathrm{SiO}_{2}$ ナノ粒子の みを回収した粒子の様子を示す。PEI-OA 会合体で表面処 理した $\mathrm{SiO}_{2}$ ナノ粒子との混合操作によって、 $\mathrm{Ni}$ 微粒子上 に $\mathrm{SiO}_{2}$ ナノ粒子が効果的に固定化されていることが明らか である。また、同図中には $20 \mathrm{vol} \%$ となるように Ni 微粒子
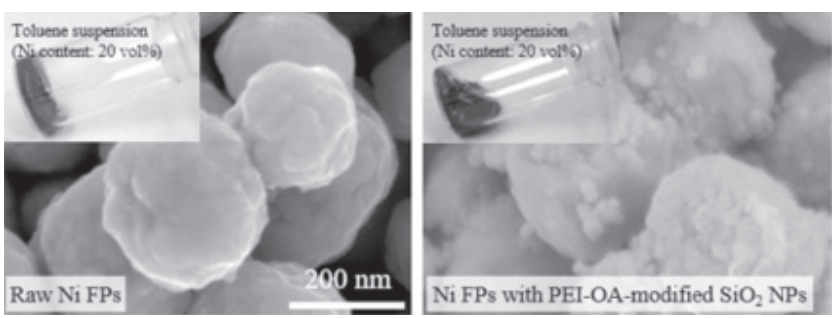

Fig.7 FE-SEM images and 20 vol\% toluene slurry of Ni with/without surface modified $\mathrm{SiO}_{2}$ nanoparticles. (Reprinted from Ref. 17, Copyright 2016, with permission from Elsevier.)

をトルエンに分散したスラリーの様子を示したが、Ni 微粒 子のみの場合ではスラリーが増粘、固化していた一方で、 PEI-OA 会合体により表面処理した $\mathrm{SiO}_{2}$ ナノ粒子の固定化 に伴ってスラリーは流動化した。

\section{5. まとめ}

本稿では機能性微粒子・ナノ粒子の非水系溶媒中におけ る均一分散化に必要な、微粒子材質や分散媒に応じた表面 設計指針とその事例を概説した後、カチオン性高分子とア ニオン性界面活性剤で表面処理した機能性ナノ粒子を用い た湿式複合化現象に基づくナノ粒子の分散状態を保った配 列化手法や、機能性ナノ粒子の分散配列制御を実現するた めのより簡便な表面処理法の一端を紹介した。湿式材料プ ロセスにおける複合材料の高機能化や新概念材料の創製に 向けては、着目している材料系や機能に応じた微粒子・ナ ノ粒子の精密なプロセッシングが求められるが、本稿がそ の実現に向けた一助となれば幸いである。

\section{謝 辞}

本報の一部は、日本板硝子材料工学助成会研究助成 (No.14-005) およびホソカワ粉体工学振興財団の助成のもと 得られた成果である。ここに記して謝意を表する。

\section{引用文献}

1) 飯島志行 : 色材協会誌、89 (2016) 163-167.

2) 飯島志行 : 粉体工学会誌、47 (2010) 481-484.

3) 飯島志行、神谷秀博 : オレオサイエンス、11 (2011) 243 -248.

4) 飯島志行、神谷秀博: 粉体技術、4 (2012) 1104-1109.

5) 飯島志行、田嶋真一、山崎美和、神谷秀博 : 粉体工学会誌、 49 (2012) 108-115.

6) M. Iijima, M. Kobayakawa, M. Yamazaki, Y. Ohta and H. Kamiya: J. Am. Chem. Soc., 131 (2009) 16342-16343.

7) M. Iijima, M. Kobayakawa and H. Kamiya: J. Colloid and Interface Sci., 337 (2009) 61-65.

8) M. Iijima, S. Takenouchi, I. W. Lenggoro and H. Kamiya: Adv. Powder Technol., 22 (2011) 663-668.

9) M. Iijima, K. Sato, K. Kurashima, T. Ishigaki and H. Kamiya: 
Powder Technol., 181 (2008) 45-50.

10) M. Iijima and H. Kamiya: Langmuir, 26 (2010) 17943-17948.

11) M. Iijima, A. Kurumiya, J. Esashi, H. Miyazaki and H. Kamiya: Proc. SPIE, 9176 (2014) 91760I.

12) 竹林賢治、笹辺修司、飯島志行、神谷秀博：粉体工学会誌、 47 (2010) 310-316.

13) M. Iijima, M. Yamazaki, Y. Nomura and H. Kamiya: Chem. Eng. Sci., 85 (2013) 30-37.
14) M. Iijima, K. Oguma, A. Kurumiya and H. Kamiya: Colloids and Surf A, 452 (2014) 51-58.

15) M. Iijima and H. Kamiya: Colloids and Surf A., 482 (2015) 195-202.

16) M. Iijima, N. Okamura and J. Tatami: Ind. Eng. Chem. Res., 54 (2015) 12847-12854.

17) S. Morita, M. Iijima and J. Tatami: Adv. Powder Technol., In press (http://dx.doi.org/10.1016/j.apt.2016.06.031). 